\title{
Rutaceae: conservation at Eka Karya Bali Botanic Garden and its in vitro antifungal activity screening
}

\author{
I Putu Agus Hendra Wibawa ${ }^{1}$, Arrohmatus Syafaqoh Li'aini ${ }^{1 *}$, Putri Sri Andila ${ }^{1}$, and Frelyta Ainuz Zahro'² \\ ${ }^{1}$ Eka Karya Bali Botanic Garden, Research Center for Plant Conservation and Botanic Gardens, \\ Indonesian Institute of Sciences \\ Candikuning, Baturiti, Tabanan, Bali 82191, Indonesia \\ ${ }^{2}$ Faculty of Agriculture, Universitas Brawijaya \\ Jl. Veteran, Ketawanggede, Lowokwaru, Malang, East Java 65145 Indonesia \\ *Corresponding author: syafa.liaini@gmail.com
}

\section{Article Info}

Received : $05^{\text {th }}$ November 2020

Revised : $03^{\text {rd }}$ February 2021

Accepted: 08 ${ }^{\text {th }}$ February 2021

Keywords:

Herbarium, inhibitory effect, methanolic extract, mycelial growth, pathogenic fungi

\begin{abstract}
Several species of Rutaceae have been widely used and commercialized in all regions in Indonesia. Some species of Rutaceae are consumed as fresh fruit and traditional medicine for various kinds of diseases, as well as to add aroma to various Indonesian culinary. Since 1959, Eka Karya Bali Botanic Garden (Eka Karya BBG) has successfully collected dozens of Rutaceae species with unknown potential. In addition to reporting the conservation of Rutaceae in Eka Karya BBG, this study aimed to screen the antifungal activity of Rutaceae methanolic extract toward Aspergillus niger, Cladosporium sp., and Fusarium solani. Leaves of 13 species of Rutaceae (Boenninghausenia sp., Citrus aurantifolia, C. maxima, C. medica, Clausena sp., Melicope sp., Micromelum sp., Murraya paniculata, Toddalia sp., Zanthoxylum sp., Z. alatum, Z. limonella, and Z. ovalifolium) were collected, cleaned, air-dried, soaked in methanol for three days, then evaporated using a rotary evaporator to obtain the plant crude extract. The in vitro inhibitory assay was conducted by the diffusion method. As a result, only $C$. medica, Clausena sp., and Z. limonella exhibited antifungal activity against those tested fungi. Their antifungal activity increased on day 2 post-treatment but slowly decreased on day 3. Thus, the result of this experiment can be used as preliminary data to research Rutaceae plant extracts as an alternative method to control pathogenic fungi. However, further research is needed to maintain and increase its inhibitory effect.
\end{abstract}

\section{INTRODUCTION}

Rutaceae, a family of the order Rutales, are shrubs and woody plant with infrequently thorny stems. Rutaceae has single leaves without stipula, entire leaf margin, glabrous leaf surface, and has oil glands. Rutaceae has a single flower with 4 to 5 white sepals, facing inward anthers, and the number of stamens is similar to the number of the sepals. The fruit of Rutaceae is hesperidium type with round shape, and the skin of the fruit has 3 layers, in which the inner layer is insulated to form a space fulfilled with water bubbles (Weiss,1997).
Several species of Rutaceae have been widely used and commercialized in almost all regions in Indonesia. The leaves of Citrus aurantifolia and $C$. hystrix, as well as the fruit of $C$. aurantifolia, are used to eliminate the fishy odors and add aroma to various Indonesian culinary (Apriliani et al., 2014; Hulyati et al. 2014). Traditionally, the fruit of $C$. aurantifolia is also used to relieves cough (Meliki et al., 2013; Hulyati et al., 2014; Slamet and Andarias, 2018), while the fruit of $C$. hystrix is usually used to treat varicella disease (Yassir and Asnah, 2019). Moreover, the fruit of $C$. aurantifolia and its skin are used to treat heart disease, hypertension, and

How to cite: Wibawa, I.P.A.H., Li'aini, A.S., Andila, P.S., and Zahro', F.A. (2021). Rutaceae: conservation at Eka Karya Bali Botanic Garden and its in vitro antifungal activity screening. Ilmu Pertanian (Agricultural Science), 6(2), pp. 108-116. 
rheumatism (Meliki et al., 2013). Additionally, Novitasari et al. (2014) mentioned that the essential oil of $C$. microcarpa had a strong anti-termite activity, while the leaves of Aegle marmelos and C. maxima were used to regrow the hair-loss as the chemotherapy effect and to treat toothache, respectively (Slamet and Andarias, 2018).

Recent studies exhibit the anti-microbial activity of some Rutaceae species. However, the study about the antifungal activity of Rutaceae is still limited. The essential oil of $C$. aurantiifolia, $C$. aurantium, and $C$. limetta strongly inhibits Escherichia coli, Staphylococcus aureus, S. mutans, Lactobacillus acidophilus, and Candida albicans (Miller et al., 2014). C. albicans is also inhibited by the presence of Zanthoxylum zanthoxyloides root extract and $Z$. macrophylum leaf extract (Kosh-Komba et al., 2017).

Stem extract of Toddalia asiatica exhibits strong inhibition toward E. coli and S. aureus (Maarisit and Lawani, 2020). Moreover, Aegle marmelos leaf extract has significantly inhibited the growth of dermatophytic fungi, such as Trichophyton mentagrophytes, $T$. rubrum, Microsporum canis, M. gypseum, and Epidermophyton floccusum (Balakumar et al., 2011).

Plants exploitation without conservation can lead to plant extinction in the future. Therefore, it is necessary to conserve, protect, and preserve it. Among all the plant species included in Rutaceae, Eka Karya Bali Botanic Garden (Eka Karya BBG) has successfully collected dozens of them since 1959. However, there are still many species collected with unknown potential. In addition to reporting the conservation of Rutaceae at Eka Karya BBG, this study aimed to screen the antifungal activity of Rutaceae. Methanol leaves extracts of 13 species of Rutaceae plant collection at Eka Karya BBG were expected to inhibit the growth of causal agents of major diseases in horticultural crops, namely Aspergillus niger, Cladosporium sp., and Fusarium solani.

\section{MATERIALS AND METHODS}

This study was conducted at the Laboratory of Applied Botany, Eka Karya BBG, from June to July 2018. Thirteen species of Rutaceae plant collections of Eka Karya BBG were used in this study, including Boenninghausenia sp., Citrus aurantifolia, C. maxima, C. medica, Clausena sp., Melicope sp., Micromelum sp., Murraya paniculata, Toddalia sp., Zanthoxylum sp., Z. alatum, Z. limonella, and Z. ovalifolium. Leaves were cleaned by running water then cut into small pieces to enlarge the surface area and speed up the drying process. Leaves were then air-dried for 3 to 6 days. Dried leaves were then soaked in the sealed Erlenmeyer filled with methanol for 3 days, and this process is called maceration, intended to soften and destroy plant cell walls to release the soluble phytochemicals. The soaked leaves were stirred once a day by slowly shaking the Erlenmeyer. After 3 days, the soaked leaves were filtered using filter paper to obtain the maceration products. The maceration products were then evaporated in IKA RV10 rotary evaporator to obtain the plant crude extract.

Aspergillus niger, Cladosporium sp., and Fusarium solani were used as the pathogen in this study. All fungal isolates were the collections of Faculty of Biology, Udayana University. Each fungus was cultured on potato dextrose agar (PDA). Ten milliliters of sterile distilled water were poured into the cultured fungi. Spores were rubbed using ose to mix it with sterile distilled water to obtain the fungal suspension, then poured into a sterile bottle. To assay the inhibitory activity of Rutaceae crude extracts against fungi, $100 \mu \mathrm{L}$ of each fungal suspension was added in the molten PDA, then plated in a Petri dish. After the PDA was set, a sterile filter paper was put in the center. Each $50 \mu \mathrm{L}$ of plant crude extracts was dripped on the filter paper, then incubated at $22^{\circ} \mathrm{C}$ for 3 days. Meanwhile, $50 \mu \mathrm{L}$ of methanol was dripped on filter paper as a control. The diameter of the clear zone was measured using a caliper.

\section{RESULTS AND DISCUSSION}

Up to September 2019, Eka Karya BBG, has collected 139 plant numbers from 16 genera of Rutaceae (Figure 1). Above all, species from some genera, such as Citrus, Zanthoxylum, and Melicope were the most collected in Eka Karya BBG (Figure 1a). Citrus collection consists of 28 plant numbers, including C. aurantifolia (3 plant numbers), C. aurantium (1), C. amblycarpa (2), C. hystrix (1), C. maxima (10), C. medica (3), C. japonica (1), C. nobilis var. microcarpa (1), Citrus $\times$ aurantium (1), and Citrus sp. (5). Comparatively, Melicope collection consists of 18 plant numbers, comprising 1 plant number of $M$. confusa, 9 M. latifolia, $1 \mathrm{M}$. lunu-akenda, and 7 Melicope sp. Meanwhile, Zanthoxylum collection consists of 15 plant numbers, 
(A)

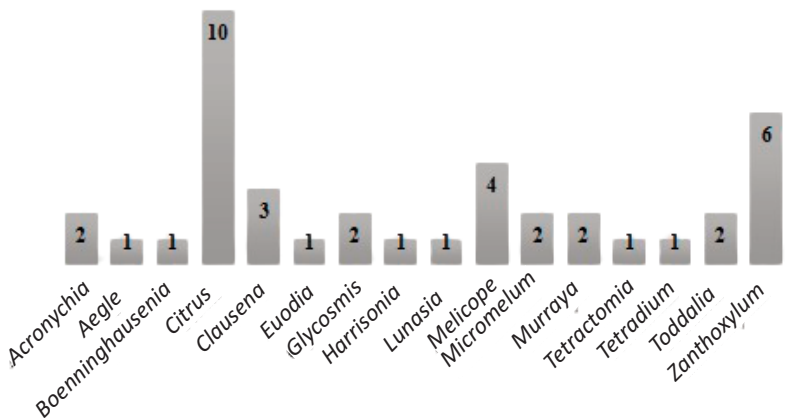

(B)

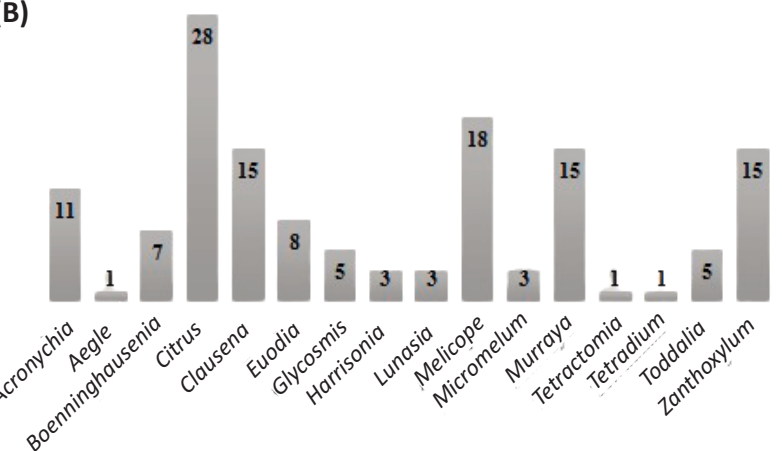

Figure 1. Genus of Rutaceae plants collected in Eka Karya Bali Botanic Garden A: total species collected in each genus, B: total number of the plant collected

which are 2 Z. armatum, 3 Z. limonella, 2 Z. ovalifolium, 2 Z. paniculatum, 1 Z. rhetsa, and 5 Zanthoxylum sp. Similarly, each Clausena and Murraya collection consists of 15 plant numbers as follows $C$. excavata (3), C. harmandiana (1), Clausena sp. (11), Murraya sp. (2), and M. paniculata (13) (Figure 1b).

Apart from the living plant collection, Eka Karya BBG collects plants in the form of herbarium as well. Herbarium is part of a plant that has been preserved by certain techniques and is generally used for scientific purposes (Mertha et al., 2018). As an ex-situ plant conservation site, the herbarium of Eka Karya BBG has a role to store and preserve plant diversity, as well as facilitate the identification or re-identification process. Among 40 species of Rutaceae collected in Eka Karya BBG, only 24 species have been collected as herbarium, such as Citrus medica, C. maxima, Zanthoxylum armatum, Z. ovalifolium, Murraya paniculata, and Boenninghausenia albiflora.

The present study was designed with the attention of safer and effective bioactive agents to investigate the activity of plant extract against fungi. Plant sources used in this study were the collection of Eka Karya BBG, which were selected for the following steps including extraction and screening methods. However, collecting plant extract still becomes a challenge since the plant is rich in bioactive compound. Since the extraction method is an important part of collecting plant extracts, methanolic crude extracts were used in this study to minimize the analogous compounds of the yield. The polarity of methanol organic solvent has been confirmed to provide the ability to extract a variety of bioactive molecules and influence both the qualitative and quantitative composition of the active compounds into plant extract (Njeru et al., 2015). Antifungal activity of plant extracts was evaluated by measuring the inhibitory effect on different species of Rutaceae against Aspergilus niger, Cladosporium sp., and Fusarium solani, as shown in Table 1 . Those three fungi are widely known as phytopathogens in such crops. Fusarium $\mathrm{sp}$. was found as a disease causative agent on dragon fruit and sugar cane, (Pinaria and Assa, 2017; Andriastini et al., 2018), while Fusarium solani was reported as a disease causative agent on lychee and bean (Pinaria and Assa, 2017). Based on the finding of Soesanto et al. (2012), Fusarium oxysporum and Cladosporium musae were included in 2 of 5 important disease-causing pathogens in bananas. Widodo and Wiyono (2012) reported a new plant disease known as leaf curling on papaya caused by Cladosporium cladosporioides. In addition, Aspergillus niger was reported to be the causal agent of crown rot, pod rot, and seed rot in peanuts, as well as black rot in onions (Pinaria and Assa, 2017).

Among 13 plant extracts, only Citrus medica, Clausena sp., and Zanthoxylum limonella confirmed activities against three tested fungi, while other species were unable to inhibit the mycelial growth of the fungi. It must be remembered that just because the activity cannot be detected from these species, it doesn't mean that there is no activity showed in this condition, and the reasons should be varied. Crude extracts are a complex mixture of many plant metabolites synthesized by plants which variations in the chemical properties modify their antimicrobial activity (Osman et al., 2012; Azwanida, 2015). Additionally, solvents play an important role in the natural product. Different use of each solvent resulted in different chemical compositions of the crude extracts (Gopalasatheeskumar et al., 2017; Truong, 2019). Nandan and Vangalpati (2015) found 
Table 1. Inhibitory effects of Rutaceae plant extracts against fungal pathogens on the day 2 post-treatment

\begin{tabular}{lccc}
\hline \multirow{2}{*}{ Plant extracts } & \multicolumn{3}{c}{ Clear zone diameter (cm) } \\
\cline { 2 - 4 } Control & 0.00 & 0.00 & 0.00 \\
Boeninghausenia sp. & 0.00 & 0.00 & 0.00 \\
Citrus aurantifolia & 0.00 & 0.00 & 0.00 \\
C. maxima & 0.00 & 0.00 & 0.00 \\
C. medica & 1.45 & 1.70 & 1.58 \\
Clausena sp. & 1.66 & 1.48 & 1.73 \\
Melicope sp. & 0.00 & 0.00 & 0.00 \\
Micromelum sp. & 0.00 & 0.00 & 0.00 \\
Murayya paniculata & 0.00 & 0.00 & 0.00 \\
Toddalia sp. & 0.00 & 0.00 & 0.00 \\
Zanthoxylum sp. & 0.00 & 0.00 & 0.00 \\
Z. alatum & 0.00 & 0.00 & 0.00 \\
Z. limonella & 2.45 & 2.08 & 2.60 \\
Z. ovalifolium & 0.00 & 0.00 & 0.00 \\
\hline
\end{tabular}

that quercetin, rutin, and kaempferol in C. medica methanolic extract were higher than other solvents such as ethanol, ethyl acetate, and water. In diffusion assay, the appearance of the inhibition zone can be detected as a clear zone formed between the disk and hypha, which indicates that there is no mycelial growth between them (Horváth et al., 2016).

In this study, the biological activity of $C$. medica, Clausena sp., and Z. limonella was exhibited as potent antifungal agents. This was proved by the formation of clear zones of inhibition around the filter paper on the agar plate containing plant crude extract. On the other hand, there was no clear zone formed in the control treatment. This indicated that the clear zone formed in C. medica, Clausena sp., and $Z$. limonella were caused by plant extracts, not the solvent of the extracts. The qualitative phytochemical investigation by Panara et al., (2012), Adham (2015), and Kalariya et al. (2019) exhibited the presence of carbohydrates, amino acids, alkaloids, flavonoids, phenols, tannins, steroids, and glycosides in C. medica. Similarly, alkaloids, flavonoids, glycosides, phenols, and tannins were also found in the methanolic extract of Clausena excavata (Elumalai and Kasinathan, 2016). Additionally, Negi et al. (2011) and Devi et al. (2015) reported the presence of alkaloids, coumarins, proteins, phenols, tannins, flavonoids, glycosides, steroids, and terpenoids in Z. limonella methanolic extracts. Those chemical compounds have been widely reported to have a broad spectrum of biological activities, including their antifungal properties.

The screening method for antifungal activity was evaluated quantitatively, observed through the diameter of the inhibition zone on the agar plate two days post-treatment, which ranged from $1.45 \mathrm{~cm}$ to $2.60 \mathrm{~cm}$, created by three plant species mentioned before (Table 2). Based on the diameter of the inhibitory zone formed by $C$. medica against $A$. niger, Clodosporium sp., and $F$. solani, the inhibition of C. medica on Cladosporium sp. was higher than other tested fungi. Chen et al. (2019) revealed that antifungal properties called D-limonene and $\mathrm{\gamma}$ terpinene contained in $C$. medica were effective to inhibit the growth of $F$. solani in Panax notoginseng. Interestingly, among three Citrus species assayed in this study, only $C$. medica showed inhibitory effects against fungal colonies (Table 1 ). It demonstrates that the crude extract from each species has characteristic and component to offer bioactivity against fungi. A previous study evaluated the effects of Citrus plant extract, including C. bergamia, C. aurantium, $C$. sinensis, $C$. deliciosa, and $C$. limon against fungal colonies and resulted that only $C$. limon was unable to inhibit the mycelial growth of $A$. flavus (Restuccia et al., 2019). 
This study displayed the ability of Clausena sp. and $Z$. limonella to restrict the growth of $F$. solani compared with other fungi. The maximum inhibitory zone on Clausena sp. was recorded up to $1.73 \mathrm{~cm}$, followed by $1.66 \mathrm{~cm}$ on $A$. niger and $1.48 \mathrm{~cm}$ on Cladosporium sp. This finding was supported by Kumar et al. (2012), which demonstrated that a new $\gamma$-lactone coumarin, named excavarin-A contained in leaves of Clausena, had been proven to be able to inhibit the pathogenic fungi in plants and human. Among the tested extracts, $Z$. limonella exhibited the greatest inhibitory effect (Table 1). The inhibitory zone caused by $Z$. limonella extracts against $F$. solani, A. niger, and Cladosporium sp. were $2.6 \mathrm{~cm}, 2.45 \mathrm{~cm}$, and $2.08 \mathrm{~cm}$, respectively. On the contrary, the lowest activity of these three potent extracts was recorded in $C$. medica against $A$. niger with a diameter of 1.45 $\mathrm{cm}$. The range between both the highest and the lowest activity explained that the presence of antifungal properties in C. medica, Clausena sp., dan Z. limonella were considered to provide defense mechanisms against fungi. These varied diameters are correlated with a combination of phytochemical compounds, fungal tolerance in the environment (Sah et al., 2011), and other genetic characteristics of the fungal (Walker dan White, 2018). Correspondingly, Supabphol and Tangjitjareonkun (2014) reported that dictamine derived from $Z$. limonella was effectively suppressed the growth of Cladosporium cucumerinum and Pyricularia oryzae. Besides, the essential oil of $Z$. limonella possessed inhibitory activity against $A$. flavus, $A$. ochraceus, $A$. parasiticus, and F. moniliforme (Nanasombat and Wimuttigosol, 2011). Another study described an antifungal activity of pinocembrocide in Z. limonella possessed toxic activity against Penicillium italicum by suppressing mycelial growth via cell membrane/wall-targeting mechanism (Chen et al., 2020).

For further analysis, the activities of selected plant crude extracts were observed to evaluate the persistence effect against tested fungi. As shown in Figure 2, the inhibitory activity of methanolic extract
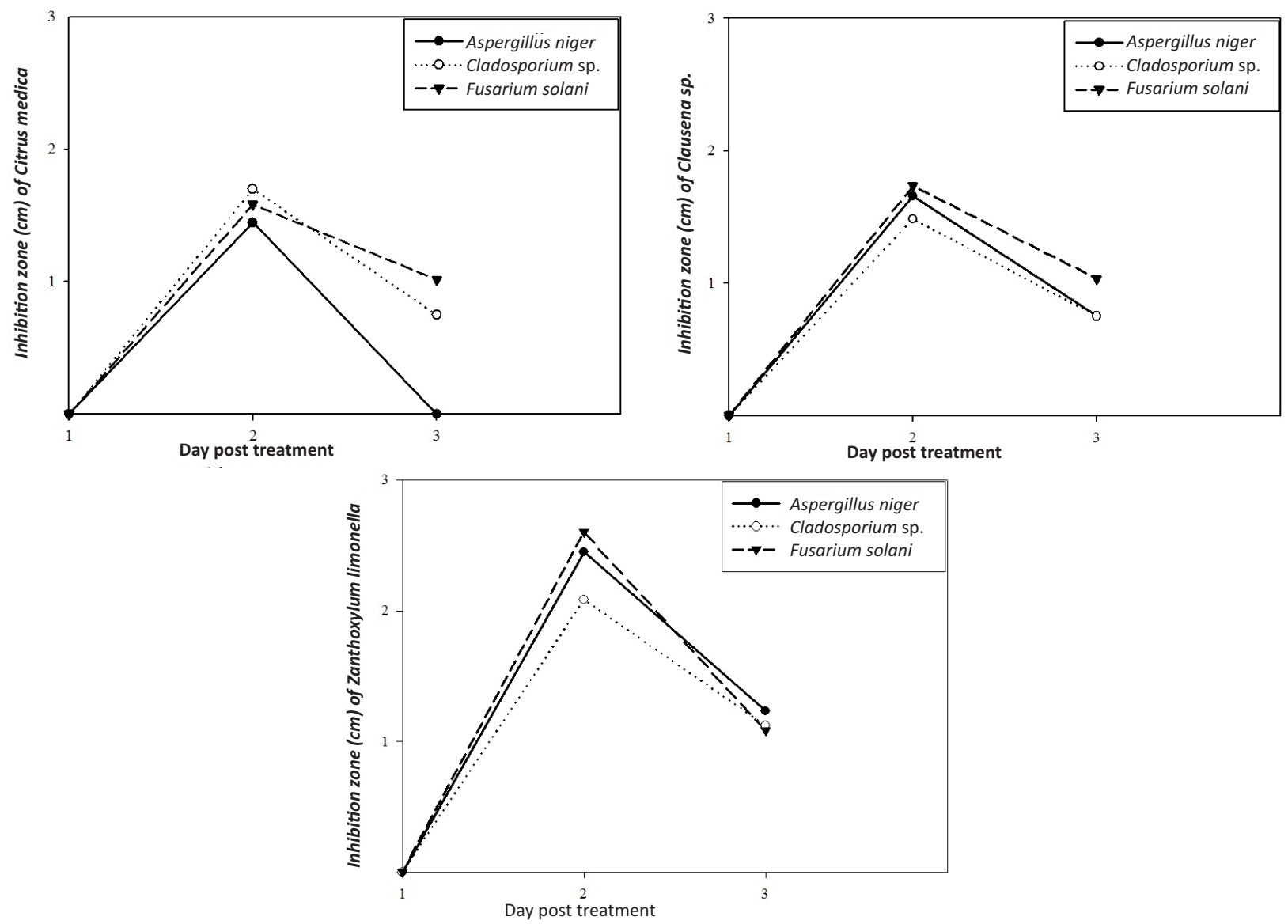

Figure 2. Inhibitory zone of Citrus medica, Clausena sp., and Zanthoxylum limonella extract against Aspergillus niger, Cladosporium sp., and Fusarium solani on day 2 and 3 post-treatment 


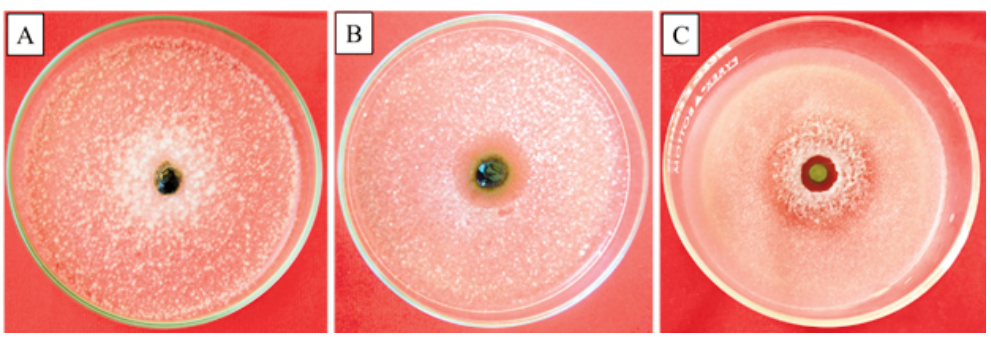

Figure 3. Antifungal activity of Citrus media methanolic extract against A: Aspergillus niger, B: Cladosporium sp., and C: Fusarium solani on day 3 post-treatment

of C. medica, Clausena sp., and Z. limonella on PDA increased on day 2 post-treatment, and became lower on day 3. Z. limonella showed the strongest activity against all three fungi (Table 1 , Figure 2 ), but the antifungal effect decreased on three species with different degrees. As presented in Figure 3, the inhibitory activity of $C$. medica against $A$. niger was completely suppressed on day 3 post-treatment, while others still showed their ability to restrict the mycelial growth during the same period of incubation (Figure 3). Two possibilities could be described that either persistency of active compound contained in $C$. medica was low, or the type of $A$. niger strain assayed here had high pathogenicity. It is not a surprise since the natural product has been known as biodegradable and non-persistent compounds. Wibawa et al. (2019) mentioned that the inhibition of the methanolic extract only lasted until the second day and faded on the third day, which is probably because the active ingredients of the extract are volatile compounds.

This study was carried out to find the potency of Rutaceae as antifungal agents in supporting awareness of the negative effects of synthetic preservatives. The results (Figure 2 ) indicate that selected crude extracts show a short time ability to inhibit the mycelial growth of fungi. Of all the tested extracts, only C. medica, Clausena sp., and Z. limonella effectively inhibited the fungal growth. This indicates that only those three plant species contain chemical compounds with antifungal properties. The content of compounds in plants can be varied depending on some factors, including genetics, season, and habitat (You et al., 2011; Wibawa et al., 2019a). Cantín et al. (2012) mentioned that there were large differences in phytochemical profiles between genotypes and/or cultivars of the same species. Recent studies have also shown that environmental conditions and seasons have an impact on the content of plant chemical compounds (Howard et al., 2003; Crespo et al., 2010; Kruger et al., 2011; Wibawa and Lugrayasa, 2020). Phytochemical properties contained in plant sources are expected to contribute to this inhibitory activity. Pavela (2014) and Jiménez-Reyes et al. (2019) declared that the persistent effect of phytochemical property is a relatively short time. This is because the compounds are released in the surrounding environment, thereby limiting the efficacy. On the other hand, synthetic preservatives could be long-term persistent and potentially toxic to organisms (Lushchak et al., 2018).

Rutaceae is one of the plant families that comprise approximately 160 genera, known as potent antimicrobial agent and used traditionally as medicine for some diseases. These roles should be correlated with the properties contained in each plant. Generally, the secondary metabolites are non-essential properties in plant development that contribute to plant survival (Pagare et al., 2015). Referring to the recent topic about plant extract, many plant species offer as antifungal agents in food source and public health. These cases have been a major concern since the spread of plant pathogens can influence the deterioration of food throughout the world (Costa et al., 2013). In this case, some mycotoxins are secreted by fungus from the genera of Fusarium, Aspergilus (Jimenez-Garcia et al., 2018), and Cladosporium (Alwatban, 2014). Fortunately, Rutaceae is one of the solutions. Furthermore, this investigation of the antifungal activity of Rutaceae could be an important step towards the possibilities of using the natural product in plant protection and food safety. This may imply that its ability as an antifungal agent is undoubtedly, but it needs more attention to carry out understandings and future research. So, further analysis is needed to investigate its potential and activity such as chemical compounds, efficiency, 
resistance to pathogens, and environmental risks. Supported by any previous studies, the basis of this study allows promising probability to explore another potency of Rutaceae not only as antifungal agents but also other biological effects.

\section{CONCLUSIONS}

As a plant conservation site in eastern Indonesia, Eka Karya BBG has collected 139 plant numbers from 16 genera of Rutaceae. Most collections are from Bali, West Nusa Tenggara, and East Nusa Tenggara. In addition to the living collection, Eka Karya BBG also collects plants in the form of herbarium. Among 40 species of Rutaceae collected, only 24 species have been collected as herbarium.

The assay of in vitro antifungal activity of Rutaceae exhibited that among 13 plant extracts, only C. medica, Clausena sp., and $Z$. limonella inhibited the growth of $A$. niger, Cladosporium sp., and $F$. solani. The strongest inhibitory effect was shown by $Z$. limonella methanolic extract. Generally, the antifungal activity of $C$. medica, Clausena sp., and Z. limonella increased on day 2 post-treatment, but slowly decreased on day 3. Thus, the result of this experiment can be used as the preliminary data to research Rutaceae plant extracts as an alternative method to control pathogenic fungi. However, further research is needed to maintain and increase its inhibitory effect.

\section{ACKNOWLEDGMENTS}

Authors are grateful to I Gusti Made Sudirga, I Nyoman Sudiatna, Agung Kurniawan, Haruly Merriansyah, and I Wayan Armawa from Registration Unit of Eka Karya BBG for providing the data of Rutaceae plants collected in Eka Karya BBG.

\section{REFERENCES}

Alwatban, M.A., Hadi, S., and Moslem, M.A. (2014). Mycotoxin production in Cladosporium species influenced by temperature regimes. J. Pure Appl. Microbiol., 8(6), pp. 4061-4069.

Adham, A.N. (2015). Phytochemical analysis and evaluation antibacterial activity of Citrus medica peel and juice growing in Kurdistan/ Iraq. Journal of Applied Pharmaceutical Science, 5(10), pp. 136-141.
Andriastini, D.A., Ramona, Y., and Proborini, M.W. (2018). Hambatan in vitro cendawan antagonis pada Fusarium sp., penyebab penyakit pada tanaman buah naga (Hylocereus undatus (Haw.) Britton \& Rose). Jurnal Metamorfosa, 5(2), pp. 224-233.

Apriliani, A., Sukarsa, and Hidayah, H.A. (2014). Kajian etnobotani tumbuhan sebagai bahan tambahan pangan secara tradisional oleh masyarakat di Kecamatan Pekuncen Kabupaten Banyumas. Scripta Biologica, 1(1), pp. 76-84.

Azwanida, N. (2015). A Review on the extraction methods use in medicinal plants, principle, strength and limitation. Med. Aromat. Plants, 4(3), pp. 1-6.

Balakumar, S., Rajan, S., Thirunalasundari, T., and Jeeva, S. (2011). Antifungal activity of Aegle marmelos (L.) Correa (Rutaceae) leaf extract on dermatophytes. Asian Pasific Journal of Tropical Biomedicine, 1(4), pp. 309-312.

Cantín, C.M., Minas, I.S., Goulas, V., Jiménez, M., Manganaris, G.A., and Michailides, T.J. (2012). Sulfur dioxide fumigation alone or in combination with $\mathrm{CO}_{2}$-enriched atmosphere extends the market life of highbush blueberry fruit. Postharvest Biol. Technol., 67, pp. 84-91.

Chen, C., Chen, J., and Wan, C. (2020). Pinocembrin7-Glucoside (P7G) reduced postharvest blue mold of navel orange by suppressing Penicillium italicum growth. Microorganisms, 8(4), pp. 1-17.

Chen, C.J., Li, Q.Q., Ma, Y.N., Wang, W., Cheng, Y.X., Xu, F.R., and Dong, X. (2019). Antifungal effect of essential oils from five kinds of Rutaceae plants - avoiding pesticide residue and resistance. Chemistry \& Biodiversity, 16(4), pp. e1800688.

Costa, S.S., Arumugam, D., Gariepy, Y., Rocha, S.C.S., and Raghavan, V. (2013). Spilanthol extraction using microwave: calibration curve for gas chromatography. Chem. Eng. Trans., 32, pp. 1783-1788.

Crespo, P., Gin'e-Bordonaba, J., Terry, L.A., and Carlen, C. (2010). Characterisation of major taste and health-related compounds of four strawberry genotypes grown at different Swiss production sites. Food Chem., 122(1), pp. 16-24.

Devi, A.D., Singh, T.C., Devi, O.I., Singh, S.S., Singh, A.R., and Singh, E.J. (2015). Phytochemical analysis of some traditional aromatic plant species of Thobal District, Manipur. Asian Journal of Pharmaceutical Science \& Technology, 5(1), pp. 50-53. 
Elumalai, K. and Kasinathan, I.D. (2016). Antioxidant activity and phytochemical screening of different solvent extracts Cluasena excavate Burm.f. (Rutaceae). MOJ Ecology \& Environmental Science, 1(1), pp. 1-6.

Gopalasatheeskumar, K., Parthiban, S., Manimaran, T., and Boopathi, T. (2017). Phytochemical screening on various extracts (benzene, ethanolic, and aqueous) of stem parts of Zanthoxylum rhetsa (Roxb.) DC. International Journal of Universal Pharmacy and Bio Sciences, 6(2), pp. 79-91.

Hulyati, R., Syamsuardi, and Arbain, A. (2014). Studi etnobotani pada tradisi Balimau di Kota Pariaman, Sumatera Barat. Jurnal Biologi Universitas Andalas, 3(1), pp. 14-19.

Horváth, G., Bencsik, T., Ács, K., and Kocsis, B. (2016). Sensitivity of ESBL-producing gramnegative bacteria to essential oils, plant extracts, and their isolated compounds. In: K. Kon and M. Rai, eds., Antibiotic Resistance, $1^{\text {st }}$ ed. Amsterdam: Academic Press, pp. 239-269

Howard, L., Clark, J., and Brownmiller, C. (2003). Antioxidant capacity and phenolic content in blueberries as affected by genotype and growing season. J. Sci. Food Agric., 83(12), pp. 1238-1247.

Jimenez-Garcia, S.N., Garcia-Mier, L., FeregrinoPerez, J., Garcia-Trejo, J.F., Ramirez-Gomez, X.S., Guevara-Gonzalez, R.G., and FeregrinoPerez, A.A. (2018). Fusarium mycotoxins and metabolites that modulate their production, In: Askun, T., ed., Fusarium: Plant Diseases, Pathogen Diversity, Genetic Diversity, Resistance and Molecular Markers, $1^{\text {st }}$ ed. London, UK: IntechOpen. pp 23-40.

Jiménez-Reyes, M.F., Carrasco, H., Olea, A.F., and Silva-Moreno, E. (2019). Natural compounds: a sustainable alternative to the phytopathogens control. J. Chil. Chem. Soc., 64(2), pp. 4459-4465.

Kalariya, M.V., Prajapati, R.P., and Chavda, J.R. (2019). Pharmacognostic and phytochemical evaluation of Bijapur (Citrus medica Linn.) fruit. Journal of Pharmacognosy and Phytochemistry, 8(3), pp. 4159-4164.

Kosh-Komba, E., Toumnou, L.A., Zinga, I., Touckia, I., Lembo, P.U.N.Z.W., Mukeina, G., Semballa, S., Yongo, O.D., and Syssa-Magale, J.L. (2017). Phytochemical screening, antifungal and antibacterial effect of Zanthoxylum zanthoxyloides and Zanthoxylum macrophylum used in traditional medicine in Yamboro (Central
African Republic). European Journal of Medicinal Plants, 19(3), pp. 1-11.

Kruger, E, Dietrich, H., Schopplein, E., Rasima, E., and Kurbel, P. (2011). Cultivar, storage conditions and ripening effects on physical and chemical qualities of red raspberry fruit. Postharvest Biol. Technol., 60(1), pp. 31-37.

Kumar, R., Saha, A., and Saha, D. (2012). A new antifungal coumarin from Clausena excavata. Fitoterapia, 83(1), pp. 230-233.

Lushchak, V.I., Matviishyn, T.M., Husak, V.V., Storey, J.M., and Storey, K.B. (2018). Pesticide toxicity: a mechanistic approach. EXCLI J., 17, pp. 1101-1136.

Maarisit, W. and Lawani, M. (2020). Chemical investigation and antimicrobial activity of medicinal plant Toddalia asiatica Lam. Indones. J. Chem., 20(5), pp. 1025-1031.

Meliki, R.L. and Lovadi, I. (2013). Etnobotani tumbuhan obat oleh Suku Dayak Iban Desa Tanjung Sari Kecamatan Ketungau Tengah Kabupaten Sintang. Protobiont, 2(3), pp. 129-135.

Mertha, I.G., Agil, A.I., Ilhamdi, M.L., and Zulkifli, L. (2018). Pelatihan teknik pembuatan herbarium kering dan identifikasi tumbuhan berbasis lingkungan sekolah di SMAN 4 Mataram. Jurnal Pendidikan dan Pengabdian Masyarakat, 1(1), pp. 82-87.

Miller, A.B., Cates, R.G., Lawrence, M., Soria, J.A.F., Espinoza, L.V., Martinez, J.V., and Arbizu, D.A. (2014). The antibacterial and antifungal activity of essential oils extracted from Guatemalan medicinal plants. Pharm. Biol., 53(4), pp. 548-554.

Nanasombat, S. and Wimuttigosol, P. (2011). Antimicrobial and antioxidant activity of spice essential oils. Food Sci. Biotechnol., 20, pp. 45-53.

Nandan, M.P. and Vangalapati, M. (2015). Phytochemical analysis and effect of various parameters on the extraction yield of flavonoids from the Citrus medica L. peel extract. International Advanced Research Journal in Science, Engineering and Technology, 2(8), pp. 5-9.

Negi, J.S., Bisht, V.K., Bhandari, A.K., Singh, P., and Sundriyal, R.C. (2011). Chemical constituents and biological activities of the genus Zanthoxylum: a review. African Journal of Pure and Applied Chemistry, 5(12), pp. 412-416.

Njeru, S.N., Obonyo, M.A., Nyambati, S.O., and Ngari, S.M. (2015). Antimicrobial and cytotoxicity properties of the crude extracts and fractions of Premna resinosa (Hochst.) Schauer 
(Compositae): Kenyan traditional medicinal plant. BMC Complement. Altern. Med., 15, pp. 1-9.

Novitasari, Jayuska, A., and Wibowo, M.A. (2014). Bioaktivitas anti rayap minyak atsiri dari daun jeruk sambal (Citrus microcarpa Bunge) terhadap rayap tanah Macrotermes sp. JKK, 3(4), pp. 57-62.

Osman, K., Evangelopoulos, D., Basavannacharya, C., Gupta, A., McHugh, T.D., Bhakta, S., and Gibbons, S. (2012). An antibacterial from Hypericum acmosepalum inhibits ATPdependent MurE ligase from Mycobacterium tuberculosis. Int. J. Antimicrob. Agents, 39(2), pp. 124-129.

Pagare, S., Bhatia, M., Tripathi, N., Pagare, S., and Bansal, Y.K. (2015). Secondary metabolites of plants and their role: overview. Current Trends in Biotechnology and Pharmacy, 9(3), pp. 293-304.

Panara, K., Joshi, K., and Nishteswar, K. (2012). A review on phytochemical and pharmacological properties of Citrus medica Linn. International Journal of Pharmaceutical \& Biological Archives, 3(6), pp. 1292-1297.

Pavela, R. (2014). Limitation of plant biopesticides, In: Singh, D. (ed.). Advances in Plant Biopesticides. New Delhi: Springer, pp. 347-359.

Pinaria, A.G. and Assa, B.H. (2017). Jamur patogen tanaman terbawa tanah. $1^{\text {st }}$ ed. Malang: Media Nusa Creative.

Restuccia, C., Conti, G.O., Zuccarello, P., Parafati, L., Cristaldi, A., and Ferrante, M. (2019). Efficacy of different citrus essential oils to inhibit the growth and B1 aflatoxin biosynthesis of Aspergillus flavus. Environmental Science and Pollution Research, 26(30), pp. 31263-31272.

Sah, A.N., Juyal, V., and Melkani, A.B. (2011). Antimicrobial activity of six different parts of the plant Citrus medica Linn. Pharmacogn. J., 3(21), pp. 80-83.

Slamet, A. and Andarias, S.H. (2018). Studi etnobotani dan identifikasi tumbuhan berkhasiat obat masyarakat Sub Etnis Wolio Kota Baubau Sulawesi Tenggara. Proceeding Biology Education Conference, 15(1), pp. 721-732.

Soesanto, L., Mugiastuti, E., Ahmad, F., and Witjaksono. (2012). Diagnosis lima penyakit utama karena jamur pada 100 kultivar bibit pisang. J. HPT Tropika, 12(1), pp. 36-45.
Supabphol, R. and Tangjitjareonkun, J. (2014). Chemical constituents and biological activities of Zanthoxylum limonella (Rutaceae): a review. Tropical Journal of Pharmaceutical Research, 13(12), pp. 2119-2130.

Truong, D.H., Nguyen, D.H., Ta, N.T.A., Bui, A.V., Do, T.H., and Nguyen, H.C. (2019). Evaluation of the use of different solvents for phytochemical constituents, antioxidants, and in vitro antiinflammatory activities of Severinia buxifolia. Journal of Food Quality, 2019, pp. 1-9.

Walker, G.M. and White, N.A. (2018). Introduction to fungal physiology. In: K. Kavanagh, ed., Fungi: Biology and Applications, $3^{\text {rd }}$ ed. USA: John Wiley \& Sons, pp. 1-34

Weiss, E.A. (1997). Essential oil crops. $1^{\text {st }}$ ed. Victoria, Australia: CAB International, pp. 417-435

Wibawa, I.P.A.H., Saraswaty, V., Kuswantoro, F., Andila, P.S., Wardhani, P.K., Tirta, I.G., and Sujarwo, W. (2019). A study of essential oil from an invasive Piper aduncum L. Jurnal Biologi Udayana, 23(2), pp. 50-58.

Wibawa, I.P.A.H., Saraswaty, V., and Sujarwo, W. (2019a). Studi potensi minyak atsiri daun Boenninghausenia albiflora (Hook.) Rchb. ex Meisn. di Kebun Raya Eka Karya Bali. Buletin Kebun Raya, 22(2), pp. 73-82.

Wibawa, I.P.A.H and Lugrayasa, I.N. (2020). Studi potensi antioksidan dan antimikroba ekstrak buah lempeni (Ardisia elliptica Thunb.). Widya Biologi, 11(2), pp. 109-117.

Widodo and Wiyono, S. (2012). Penyakit keriting daun pepaya yang disebabkan oleh Cladosporium cladosporioides. Jurnal Fitopatologi Indonesia, 8(1), pp. 28-29.

Yassir, M. and Asnah. (2019). Pemanfaatan jenis tumbuhan obat tradisional di Desa Batu Hamparan Kabupaten Aceh Tenggara. BIOTIK: Jurnal IImiah Biologi Teknologi dan Kependidikan, 6(1), pp. 17-34.

You, Q., Wang, B., Chen, F., Huang, Z., Wang, X., and Luo, P.G. (2011). Comparison of anthocyanins and phenolics in organically and conventionally grown blueberries in selected cultivars. Food Chem., 125(1), pp. 201-208. 